\title{
Assay optimization for measuring the alternate complement pathway activity in Asian seabass (Lates calcarifer)
}

\author{
SRI D. HASTUTI ${ }^{1,2, \vartheta}$, MARY D. BARTON ${ }^{3}$, STEPHEN B. PYECROFT ${ }^{1}$, MAURIZIO COSTABILE ${ }^{3,4, v \vartheta}$ \\ ${ }^{1}$ School of Animal and Veterinary Sciences, University of Adelaide Australia. Adelaide, South Australia 5005, Australia. \\ ${ }^{2}$ Department of Aquaculture, Universitas Muhammadiyah Malang. Jl. Raya Tlogomas No. 246, Malang 65144, East Java, Indonesia. \\ Tel.: +62-341-4641819, Fax.: +62-341-460782. `email: sri.hastuti@adelaide.edu.au, hastuti@umm.ac.id \\ ${ }^{3}$ School of Pharmacy and Medical Sciences, University of South Australia. Adelaide, South Australia 5000, Australia \\ ${ }^{4}$ Centre for Cancer Biology, University of South Australia and SA Pathology. Frome Road, Adelaide, South Australia 5000, Australia. \\ vemail: maurizio.costabile@unisa,edu.au
}

Manuscript received: 17 February 2020. Revision accepted: 13 June 2020.

\begin{abstract}
Hastuti SD, Barton MD, Pyecroft SB, Costabile M. 2020. Assay optimization for measuring the alternate complement pathway activity in Asian seabass (Lates calcarifer). Biodiversitas 21: 3034-3040. Complement proteins are one component of innate immunity present in fish. The measurement of complement activity in fish can be used to monitor the health status of fish. This is particularly important in Asian seabass (Lates calcarifer) aquaculture, where disease can impact on productivity. We have found an optimal condition assay for measuring the alternate complement pathway (ACP) activity of Asian seabass which includes $\mathrm{Magnesium}$ chloride $\left(\mathrm{MgCl}_{2}\right)$ concentration, buffer $\mathrm{pH}$, incubation temperature and incubation time. The assay was optimized using pooled serum of Asian seabass, diluted in Magnesium ethylenediamine tetraacetic acid gelatine veronal buffer (Mg-EDTA-GVB) and added with Rabbit red blood cells (RRBC) suspension. Subsequently, the suspension was incubated and centrifuged. The supernatant was removed and transferred to a well plate and the optical density (OD) was measured at $540 \mathrm{~nm}$. The optimal condition obtained included a $7.5 \mathrm{mM} \mathrm{MgCl} 2, \mathrm{pH}$ optimum of 7.5 , $25^{\circ} \mathrm{C}$ incubation temperature, and a 30 minutes incubation period. The presently developed assay was robust, rapid, and reliable to be used in monitoring the health status of Asian seabass in aquaculture farms. It can be used as guidance in further immunological studies on this fish.
\end{abstract}

Keywords: Alternate complement pathway, ACP, Asian seabass, assay optimization

\section{INTRODUCTION}

Asian seabass is an aquaculture species that is intensively farmed in the Asia Pacific region. Disease in intensive fish aquaculture leads to economic losses due to decreased production. High standards of fish health management including regular monitoring of fish health is required to anticipate and detect the emergence of disease, so that immediate treatment can be performed to avoid mass mortality of the cultured fish. Non-specific immune parameters, such as alternate complement pathway (ACP) activity, could be important indicators of fish health.

Complement is one of immune system components that plays an important role in innate defense mechanisms, destroying microorganisms via the inflammatory reaction, direct microbial killing, opsonization, phagocytosis, immune complex elimination, and modulation of adaptive immune responses (Holland and Lambris 2002; Kirschfink and Mollnes 2003). Complement proteins are synthesized as inactive forms which can be activated through a variety of foreign substances (Holland and Lambris 2002). Three complement pathways exist, defined as the classical (CCP), lectin (LCP), and alternate (ACP) pathways (Holland and Lambris 2002). These pathways can be activated either alone or overlapping to initiate complement activity (Zhou et al. 2012).
Several outcomes of complement activation have been described such as elimination of pathogens by forming pores in the cell membrane (Holland and Lambris 2002). Phagocytosis or cytolysis of pathogens, solubilization of immune complexes, and inflammation are examples of the important roles played by complement in mediating innate immune responses (Boshra and Li et al. 2006). Apart from innate immunity, complement also plays a significant role in modulating and enhancing the adaptive immune response by binding to specific receptors forming antigenantibody complexes (Ag-Ig) through the CCP (Holland and Lambris 2002). Thus, there are substantial connections between innate and adaptive immune responses which are mediated by complement (Boshra and Li et al. 2006).

ACP activity has been reported to be between 8 to 10 fold higher in fish than in mammals (Sunyer and Tort 1995) and displays activity over a broad temperature range (Sakai 1992; Takahashi et al. 2012), suggesting that the ACP may have greater importance compared to mammals and acts as a powerful natural defense in poikilothermic organisms (Holland and Lambris 2002).

Physiological changes, such as a change in nutritional intake have been demonstrated to alter serum ACP activity in fish. For example, a diet deficient in $\alpha$-tocopherol or $n-3$ highly unsaturated fatty acids (HUFA) decreased ACP of Gilthead seabream (Montero et al. 1998). It has also been reported that increasing the level of vitamin $\mathrm{C}$ in the diet of 
Golden shiners can increase ACP levels (Chen et al. 2003). Since complement has an important role in phagocytosis and lysis of pathogens (Whyte 2007), any decrease in complement activity will increase the susceptibility of the fish to infection, while the infectious disease can further decrease ACP activity (Hayman et al. 1992).

ACP activity can be used as an indicator of innate immunity (Takahashi et al. 2012). Hence, it can be used as a rapid diagnosis of fish health status and it does not require the fish to be killed for sampling, as only a small volume of serum is required for the assay. To date, studies on fish complement are still limited and there is no information about optimum conditions for measuring complement activity in Asian seabass. Yano et al. 1988 reported different optimum conditions of ACP activity in some fish suggested that standardization of the ACP activity assay is required for each species. Therefore, the objective of this study was to determine the optimum conditions for assaying the ACP activity of Asian seabass. The main factors that were analyzed included $\mathrm{Mg}^{2+}$ ion concentration, buffer $\mathrm{pH}$, incubation temperature, and length of incubation required to measure activity. The reproducibility of the assay was also assessed.

\section{MATERIALS AND METHODS}

\section{Buffer}

The EGTA-Gelatin Veronal Buffer (EGTA-GVB) was used following the method described by Yano et al. 1988 with slight modifications. The buffer contained of $0.15 \mathrm{mM}$ $\mathrm{CaCl}_{2}$ (Chem supply, Adelaide Australia), $141 \mathrm{mM} \mathrm{NaCl}$ (Chem supply, Adelaide Australia), 0.1\% (w/v) gelatin (Biochem, Australia), $1.8 \mathrm{mM}$ Sodium barbital (Ajax chemical, Sydney Australia), $3.1 \mathrm{mM}$ Barbituric acid (Ajax chemical, Sydney Australia), $10 \mathrm{mM}$ ethylene glycol-bis [ $\beta$-aminoethyl ether]-N,N,N',N'-tetraacetic acid (EGTA) (Sigma Aldrich, Australia), and $7.5 \mathrm{mM} \mathrm{MgCl} 2$ (Chem supply, Adelaide Australia). The buffer was adjusted to $\mathrm{pH}$ 7.5 .

\section{Fish}

A total of 20 juvenile Asian seabass ranging in size from 15 to $25 \mathrm{~cm}$ in length were purchased from a local supplier (Robbara broodstock sanctuary and hatchery, South Australia). The animal research was approved by Adelaide University Animal Ethics Committee with approval number S-2015-104. Fish were kept for 12 weeks in a circular plastic tank with a diameter of $2 \mathrm{~m}$ and $1 \mathrm{~m}$ deep, equipped with a recirculation system for maintaining water quality. The water temperature was maintained at $22-$ $25^{\circ} \mathrm{C}$. The fish were fed on a commercial diet once a day near satiation.

\section{Serum}

The fish were anaesthetized using $200 \mathrm{mg} / \mathrm{L}$ AQUI-S ${ }^{\circledR}$ (AQUI-S New Zealand Ltd, Australia) and blood was collected from the caudal vein using a $1 \mathrm{ml}$ syringe with a $25 \mathrm{G}$ needle. Approximately $500 \mu \mathrm{L}$ of blood was collected from each fish and immediately centrifuged at $3000 \mathrm{~g}$ at $4^{\circ} \mathrm{C}$ for 15 minutes. The serum was removed (approximately $300 \mu \mathrm{L}$ ), pooled, aliquoted, and stored at $80^{\circ} \mathrm{C}$ until used.

Preparation of rabbit red blood cell (RRBC) suspension Rabbit Red Blood Cells (RRBC) in Alsever's solution were purchased from Applied Biological Products Management (Adelaide, Australia) and stored at $4{ }^{\circ} \mathrm{C}$ until used. On the day of use, RRBC was washed two times with EGTA-GVB by centrifugation (1000 g for 5 minutes at $22^{\circ} \mathrm{C}$ ) and suspended in the same buffer at $4 \times 10^{7}$ cells $/ \mathrm{ml}$ and used for the assay.

\section{Hemolytic activity of ACP}

Alternate complement pathway (ACP) was assayed as described by Yano et al. (1988) with some modifications. Briefly, Asian seabass serum was serially diluted in $\mathrm{Mg}$ EDTA-GVB 1:16 to $1: 64$. $100 \mu \mathrm{L}$ of RRBC suspension was added into $200 \mu \mathrm{L}$ of diluted serum, which was then incubated at specific temperatures and incubation periods. Following the incubation, the samples were centrifuged at $2000 \mathrm{~g}$ for 5 minutes at $22^{\circ} \mathrm{C}$. A total of $100 \mu \mathrm{L}$ of supernatant was removed, transferred to a 96-well flatbottom plate (Sarstedt, Germany) and the optical density (OD) was measured at $540 \mathrm{~nm}$ using a Thermo Scientific Multiskan Ascent Microplate Reader Type 354. \% lysis was calculated using the following formula: $\%$ lysis = [(OD540 test-OD540 blank)/(OD540 total lysis-OD540 blank)] x 100 (Costabile 2010).

\section{Varying $\mathrm{Mg}^{2+}$ ion concentration}

The GVB was prepared with varying concentrations of $\mathrm{MgCl}_{2}(0,0.5,1,2.5,5,7.5$ and $10 \mathrm{mM})$. Pooled Asian seabass sera were serially diluted from $1: 16$ to $1: 64$ in EGTA-GVB. Next, $100 \mu \mathrm{L}$ of RRBC suspended in GVB buffer was added into $200 \mu \mathrm{L}$ of diluted serum and was incubated at $20^{\circ} \mathrm{C}$ for 2 hours. For each assay, controls including a blank ( $200 \mu \mathrm{L}$ of the buffer without serum) and total lysis $(200 \mu \mathrm{L}$ water) were prepared for each assay. After incubation, the samples were centrifuged at $2000 \mathrm{~g} \mathrm{x}$ 5 minutes at $22^{\circ} \mathrm{C}$ and $100 \mu \mathrm{L}$ of supernatant were transferred into a 96 well flat bottom plate (Sarstedt, Germany). The absorbance was then measured at $540 \mathrm{~nm}$ using an Ascent Multiskan microplate reader.

\section{Varying pH of GVB buffer}

Pooled Asian seabass serum was serially diluted in EGTA-GVBS containing $7.5 \mathrm{mM} \mathrm{MgCl}_{2}$. The $\mathrm{pH}$ of the buffer solution was varied between 6.5, 7.0, 7.5, 8.0, 8.5, and 9.0. The ACP hemolysis reaction was performed at $20^{\circ} \mathrm{C}$ for 2 hours. The remaining steps were performed as described above.

\section{Varying incubation temperature}

Pooled Asian seabass serum was serially diluted in EGTA-GVBS buffer containing $7.5 \mathrm{mM} \mathrm{MgCl}_{2}$ at $\mathrm{pH} 7.5$ and incubated at $15,20,25$, and $30^{\circ} \mathrm{C}$ for 2 hours after addition of the RRBC suspension. The remaining steps were performed as described above. 


\section{Varying assay incubation time}

Serial dilutions of Asian seabass serum in $7.5 \mathrm{mM}$ $\mathrm{MgCl}_{2}$-EGTA-GVBS buffer at $\mathrm{pH} 7.5$ were added to $100 \mu \mathrm{L}$ of RRBC suspension at $25^{\circ} \mathrm{C}$. The samples were incubated for $0,5,10,30,60,90,120,150$ and 180 minutes and then processed as described above to determine the optimum incubation time for the ACP assay.

\section{Determining intra and inter-day variability}

Once all the above conditions were optimized, inter and intra-day variabilities were assessed. Aliquots of pooled serum samples were assayed for a total of 20 times under the optimal assay conditions $\left(7.5 \mathrm{mM} \mathrm{Mg}^{2+}, \mathrm{pH} 7.5,25^{\circ} \mathrm{C}\right.$ and 30 minutes incubation). The variability between samples at 1:64 dilution was tested over ten days.

\section{Statistical analysis}

All experiments were conducted in triplicate. The data were analyzed using GraphPad Prism 7.03 statistical software. ANOVA analysis was performed to determine the optimal concentration of $\mathrm{MgCl}_{2}, \mathrm{pH}$, temperature, and incubation time, while statistical column analysis with Levy Jennings chart was used to determine inter and intraday variabilities. The percentages of coefficient variation (CV) for inter and intra-day were also determined. A $p$ value of $<0.05$ was used for statistical significance.

\section{RESULTS AND DISCUSSION}

\section{Effect of $\mathrm{Mg}^{2+}$ ion concentration on serum ACP activity}

The presence of $\mathrm{Mg}^{2+}$ ion was essential for complement-mediated activity, with almost no lysis of rabbit red blood cells seen in its absence (Figure 1). As the levels of $\mathrm{Mg}^{2+}$ ions increased, there was a corresponding increase in RRBC lysis, with maximum lysis seen at 7.5 $\mathrm{mM}$, with no significant change above this concentration. As a result, $7.5 \mathrm{mM} \mathrm{MgCl}_{2}$ was used for all subsequent experiments.

\section{Effect of buffer pH on ACP activity}

The effect of varying buffer $\mathrm{pH}$ on serum lytic activity is shown in Figure 2. As the $\mathrm{pH}$ of the buffer raised from 6.5 , the amount of lysis increased slightly, reaching a maximum $\mathrm{pH}$ of 7.5. The data suggest that the assay is relatively robust with little difference in ACP activity for Asian seabass between pH 6.5 and 7.5. However, there was a dramatic decrease in lytic activity beyond $\mathrm{pH} 7.5$ with activity lost at $\mathrm{pH}$ higher than 8.5. This may have been due to the denaturation of protein components at this $\mathrm{pH}$. As a result, a $\mathrm{pH}$ of 7.5 was used for all experiments.

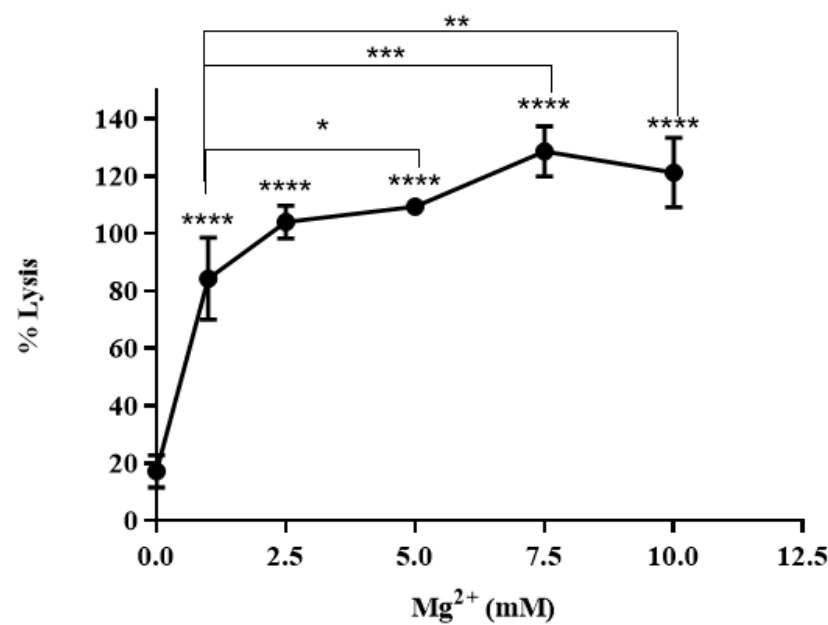

Figure 1. Effect of $\mathrm{MgCl}_{2}$ concentration on the activity of the alternate complement pathway of pooled Asian seabass serum. The pooled sera were diluted 1:16 and incubated with RRBC for 2 hours at $20^{\circ} \mathrm{C}$ with $10 \mathrm{mM}$ EGTA-GVB buffer $\mathrm{pH}$ 7. The data are shown as the percentage of haemolysis at $540 \mathrm{~nm}$ (mean \pm SEM). ANOVA was used to compare the differences between concentration of $\mathrm{MgCl}_{2}$. Data from $\mathrm{n}=3$ experiments is shown. Asterisk symbol represents significant differences among the treatments $(p \leq 0.05)$

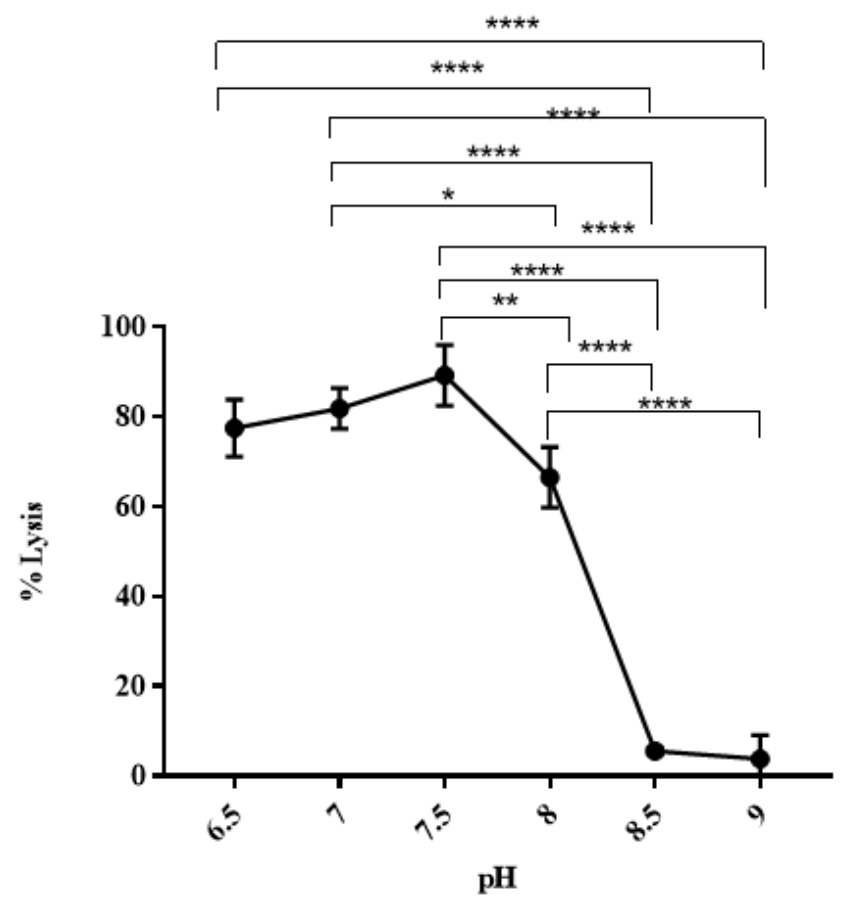

Figure 2. Effect of buffer $\mathrm{pH}$ on the alternate complement pathway activity of pooled Asian seabass serum. The pooled serum was diluted at 1:64 and incubated with RRBC for 2 hours at $20^{\circ} \mathrm{C}$ in $10 \mathrm{mM}$ EGTA and $7.5 \mathrm{mM} \mathrm{MgCl}_{2}-\mathrm{GVB}$. The data are shown as the percentage of hemolysis at $540 \mathrm{~nm}$ (mean \pm SEM). ANOVA was used to compare the differences between concentration of $\mathrm{MgCl}_{2}$. Data from $\mathrm{n}=3$ experiments is shown. Asterisk symbol represents significant differences among the treatments $(p \leq 0.05)$ 


\section{Effect of incubation temperature on ACP activity}

Previous studies on fish have suggested that there is a wide range of optimal temperatures for the activation of fish complement. We initially investigated a broad range of temperatures (Figure 3). Interestingly, there was no significant difference in serum activity at the different temperatures tested. However, maximal lysis of the RRBC was seen at an incubation temperature of $25^{\circ} \mathrm{C}$. Asian seabass is widely distributed in tropical and sub-tropical areas. It has a wide temperature tolerance ranging from 15$40^{\circ} \mathrm{C}$. The wide temperature which these fish can tolerate may be one reason why there is no difference in serum complement activity at the different temperatures tested.

\section{Effect of incubation time on ACP activity}

As with temperature, there is a range of biological activities noted in the serum from various fish species. To identify these differences, we tested a range of incubation times on serum activity (Figure 4). As little as $30 \mathrm{~min}$ incubation was sufficient to give complete lysis of the RRBCs and the lytic activity remained constant at longer incubation time. Based on the data, it was clear that 30 minutes was required for maximal complement activity using these pooled serum samples. Because 30 minutes incubation time was sufficient to yield maximal lysis, we investigated concise incubation times $(5,10$, and 20 minutes) to determine the kinetics of cell lysis (Figure 5). The results indicated that as little as 5 minutes led to a detectable increase in lytic activity, with maximum lysis seen at 30 minutes.

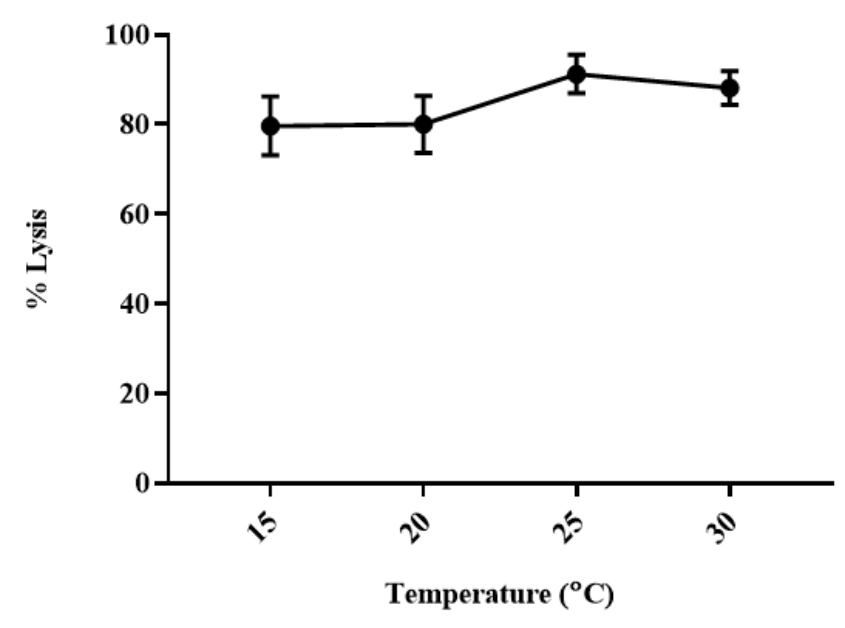

Figure 3. Effect of incubation temperature on the alternate complement pathway activity of pooled Asian seabass serum. The serum was diluted 1:64 and incubated with RRBC for 2 hours in $10 \mathrm{mM}$ EGTA, $7.5 \mathrm{mM} \mathrm{MgCl}_{2}-\mathrm{GVB}$. Values express the percentage of hemolysis at $540 \mathrm{~nm}$ (mean \pm SEM). ANOVA was used to compare the differences between temperature incubation. Data from $n=3$ experiments is shown. There are no significant differences in the lytic activity between different temperatures $(\mathrm{P} \geq 0.05)$

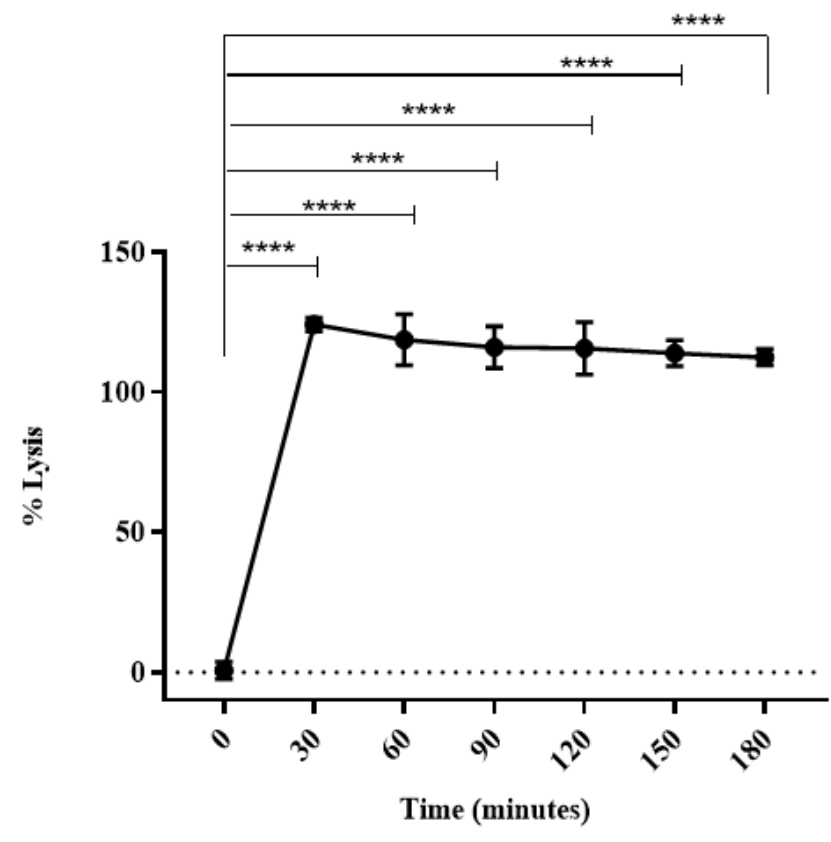

Figure 4. Effect of incubation period on the alternate complement pathway activity of pooled Asian seabass serum. The serum was diluted 1:64 and was incubated with RRBC at $25^{\circ} \mathrm{C}$ in $10 \mathrm{mM}$ EGTA, 7.5 mM $\mathrm{MgCl}_{2}-\mathrm{GVB}$ at $\mathrm{pH} 7.5$. Values express the percentage of hemolysis from the absorbance at $540 \mathrm{~nm}$ (mean \pm SEM). ANOVA was used to compare the differences between incubation time. Data from $n=3$ experiments is shown. No significant differences in the lysis activity between different time incubation from 30 to 180 minutes, except between 0 and other incubation time which is very significant

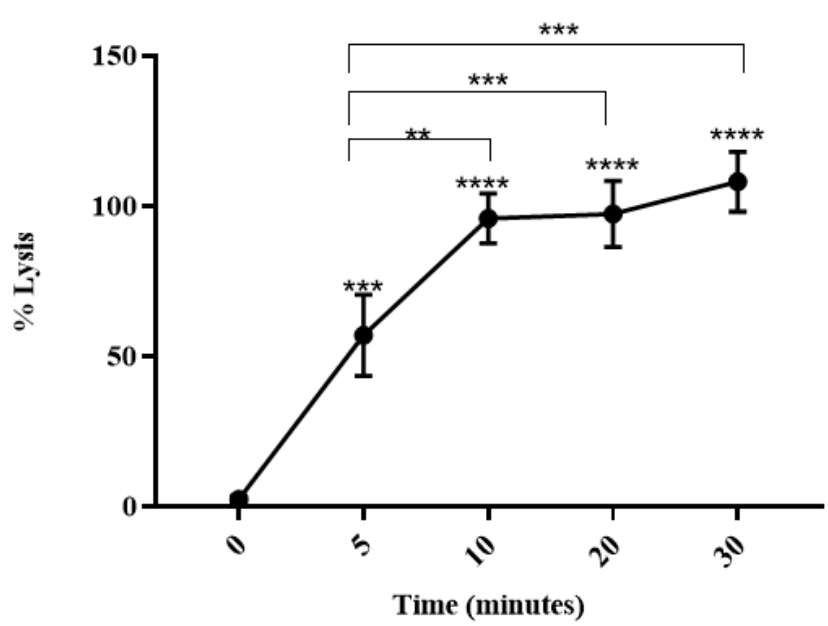

Figure 5. Effect of shorter incubation period on the alternate complement pathway activity of pooled Asian seabass serum. The serum was diluted 1:64 and incubated with $\mathrm{RRBC}$ at $25^{\circ} \mathrm{C}$ in 10 $\mathrm{mM}$ EGTA, $7.5 \mathrm{mM} \mathrm{MgCl}_{2}-\mathrm{GVB}$ at $\mathrm{pH}$ 7.5. Values express the percentage of hemolysis at $540 \mathrm{~nm}$ (mean \pm SEM). ANOVA was used to compare the differences between incubation time. Data from $n=3$ experiments is shown $(P \leq 0.05)$ 
Table 1. Intra and inter-assay variation results for complement activity between morning and afternoon for ten days

\begin{tabular}{lcc}
\hline Intra-day Variation & & \\
\hline Overall mean (n =20) & & 115.6 \\
Standard deviation & & 7.24 \\
Standard error of mean & & 1.619 \\
Coefficient variation (CV, \%) & 6.26 \\
Inter-day Variation & Morning & Afternoon \\
Overall mean (n =10) & 116 & 115.2 \\
Standard deviation & 7.55 & 7.303 \\
Standard error of mean & 2.39 & 2.309 \\
Coefficient variation (CV, \%) & 6.5 & 6.34 \\
\% CV of means (morning-afternoon) & & 6.42 \\
\hline
\end{tabular}

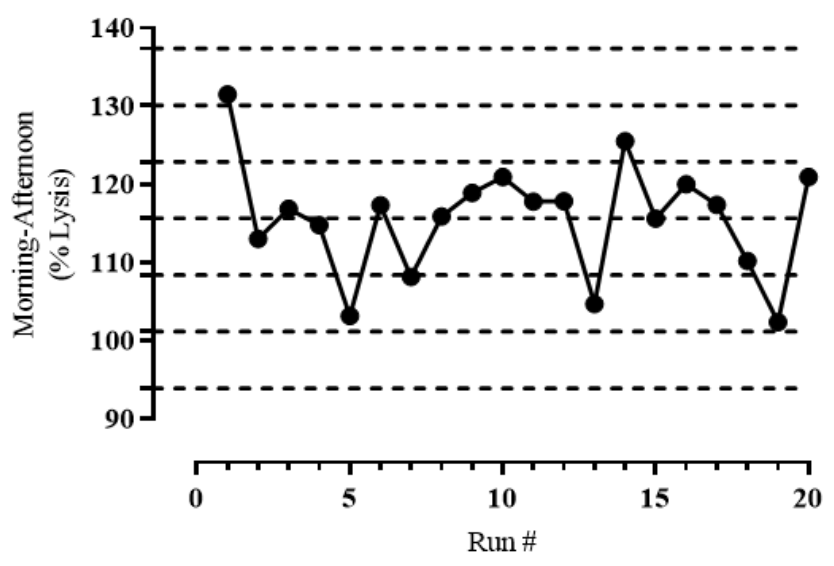

Figure 6. Investigation of intra-day variability of the assay for ACP in Asian seabass pooled serum. The serum was diluted 1:64 and was incubated with RRBC at $26^{\circ} \mathrm{C}$ in $10 \mathrm{mM}$ EGTA, $7.5 \mathrm{mM}$ $\mathrm{MgCl}_{2}-\mathrm{GVB}$ at $\mathrm{pH} 7.5$ for 30 minutes for ten days every morning and afternoon. Values express the percentage of hemolysis from the absorbance at 540 (mean \pm SEM). A paired $t$-test was used to analyze the variation of ACP between morning and afternoon. Data from $n=3$ experiments is shown. $\mathrm{CV}=6.26 \%$

\section{Assay reproducibility}

The pooled serum samples were assayed twice daily for ten days at a dilution of 1:64, a dilution where significant lysis of the RRBCs was seen. The procedure was performed to access the reproducibility of the assay. There was no significant change in serum activity over this time (Figure 6). The intra-day coefficient of variation was $6.26 \%$ (Table 1), while the inter-day coefficient of variation was $6.42 \%$, again suggesting little inter-assay variation between morning and afternoon testing. This indicates that the assay was robust and not prone to dramatic changes in lysis. Pooled serum samples can thus be reliably used as internal controls for future experimental studies.

\section{Discussion}

The assay conditions required for the assessment of the ACP differ between fish species, especially in terms of
$\mathrm{MgCl}_{2}$ concentration, $\mathrm{pH}$, temperature, and incubation time. In this study, the optimum concentration of $\mathrm{MgCl}_{2}$ was found to be $7.5 \mathrm{mM}$, while several other fish are reported to require slightly higher concentrations of $\mathrm{Mg}^{2+}$ $(10 \mathrm{mM})$ to give maximal ACP lysis (Yano et al. 1987; Sunyer and Tort 1995; Chen et al. 2003). However, it has been reported that Tinca tinca (a cyprinid fish) needs $5 \mathrm{mM}$ $\mathrm{MgCl}_{2}$ to achieve maximal ACP lysis, which is lower than any other reported studies on fish ACP (Collazos et al. 1994). $\mathrm{MgCl}_{2}$ is required to activate the ACP since in the presence of $\mathrm{CaCl}_{2}$ but with no $\mathrm{MgCl}_{2}$, deficient $\mathrm{ACP}$ activity in Asian seabass serum can be detected even at a 1:16 dilution (Figure 2). This further confirms that $\mathrm{Mg}^{2+}$ ions are required for ACP activation (Sakai 1992). $\mathrm{Mg}^{2+}$ ion enhances the hemolytic activity of complement, since it can activate both factor $\mathrm{B}$ and $\mathrm{D}$ components, and is required for the functioning of the alternate properdin pathway (Prez et al. 1975; Voght et al. 1977). Subsequently in the presence of adequate $\mathrm{Mg}^{2+}$, the membrane attack complex (MAC) will be stimulated to lyse targets (Abram et al. 2017). It has been reported that Mg-ions are crucial for complex formation by factors $\mathrm{B}$ and $\mathrm{C} 3 \mathrm{~b}$; this has been proven by studies using micro-disc electrophoresis in polyacrylamide gel concentration gradients at a stoichiometric ratio of $1: 1$ with the presence of $5-10 \mathrm{mM}$ $\mathrm{Mg}^{2+}$ (Voght et al. 1977). In addition, substituting $\mathrm{Mg}^{2+}$ with different ions such as $\mathrm{Cu}^{2+}$ or $\mathrm{Ba}^{2+}$ has not been shown to activate the ACP in Alligator serum (Merchant et al. 2005).

In terms of the optimal $\mathrm{pH}$, we found that the maximum hemolytic activity was seen at $\mathrm{pH}$ 7.5. At $\mathrm{pH}$ greater than this, there was a dramatic decrease in serum activity, and any activity was eventually lost. This may have been due to the denaturation of one of the complement components. Although $\mathrm{pH} 7.5$ was chosen, it was found that $\mathrm{pH}$ from 7.0 to 7.5 gave almost the same ACP activity, suggesting that the activity of ACP in Asian seabass functions at a neutral $\mathrm{pH}$. This is in accordance with the results from other studies (Table 1) which have found that the optimal $\mathrm{pH}$ was between 7 and 7.8 (Yano et al. 1987; Yano et al. 1988; Collazos et al. 1994; Sunyer and Tort 1995; Chen et al. 2003).

Several studies have reported that temperatures between 15 and $25^{\circ} \mathrm{C}$ gave the highest serum activity (Yano et al. 1988; Collazos et al. 1994; Sunyer and Tort 1995; Chen et al. 2003) and the activity could be detected as low as $0-4^{\circ} \mathrm{C}$ (Holland and Lambris 2002; Whyte 2007). Sunyer and Tort (1995) reported that Gilthead seabream showed observable hemolysis at very low temperatures such as $0.5^{\circ} \mathrm{C}$, while hemolytic complement activity of Channel catfish could still be detected at $3^{\circ} \mathrm{C}$ (Lobb and Hayman 1989). On the contrary, mammals need a much higher temperature for the activation of ACP with an optimal temperature at $37^{\circ} \mathrm{C}$ (Whyte 2007).

Our present study suggests that $25^{\circ} \mathrm{C}$ was the best temperature for maximum ACP activity in Asian seabass. This might be related to the optimal growing temperature required by Asian seabass, which is between 22 and $35^{\circ} \mathrm{C}$. The temperature needed to activate the complement system in fish is affected by the water temperature (Lobb and 
Hayman 1989; Sakai 1992). There was no significant difference in Asian seabass ACP when tested between 15 and $30^{\circ} \mathrm{C}, 15^{\circ} \mathrm{C}$ still gave relatively high complement activity. This finding strengthens the previous study which stated that the ACP in fish is active over a broader range of temperatures. Holland and Lambris (2002) stated that the broader and lower temperature range of fish complement occurs because fish can encounter a wide range of temperatures during summer and winter. At lower temperatures, the adaptive immune system might be slow or it might be suppressed. It has been reported that the percentage of B cells in the spleen and blood of Common carp decreases significantly when the water temperature reduces from $25^{\circ} \mathrm{C}$ to $16^{\circ} \mathrm{C}$. In addition, the number of $\mathrm{T}$ cells isolated from channel catfish decreases when fish are maintained at $11^{\circ} \mathrm{C}$ compared to $24^{\circ} \mathrm{C}$ (Abram et al. 2017). Thus, complement can support the adaptive immune function to give adequate protection to the animal until their immune response adjusts to a lower temperature and begins to function (Holland and Lambris 2002). This can be an indication that the complement system is still functional at lower temperatures when the acquired immunity is reduced (Whyte 2007). Hence, fish rely on innate immunity such as complement to protect themselves from freezing temperatures during winter (Le et al. 1998). In cold-water fish, inactivation of complement activity can be achieved by heating the serum at $40-45^{\circ} \mathrm{C}$ for 20 minutes, while serum activity of warm water species can be inactivated at $45-54^{\circ} \mathrm{C}$ (Sakai 1981; Ingram 1987). In addition, Collazos et al. (1994) reported that during winter Tinca tinca showed higher ACP activity, suggesting the importance of the complement system as a defense mechanism in fish during winter.

Our current study found that an incubation period at 30 minutes for the in vitro assay gave the maximum ACP activity in Asian seabass. This finding is different from what has been reported by others. Other studies (Yano et al. 1987; Yano et al. 1988) on seawater species such as porgy and flounder found that an incubation time of 120 minutes was required for maximal lysis of target cells. Other seawater species like seabream had an optimal incubation time of 100 minutes (Sunyer and Tort 1995), while yellowtail had a longer reaction time of 150 minutes (Yano et al. 1988). It has been reported that freshwater species have optimal incubation times shorter than seawater fish with all studies being conducted finding 90 minutes as the best incubation time for ayu, carp and tilapia (Yano et al. 1988), cyprinids (Collazos et al. 1994) and golden shiners (Chen et al. 2003). In this study, Asian seabass are maintained in freshwater environments, and the incubation period we found for activating the ACP was much shorter than that for other freshwater species. Although 30 minutes gives the maximum complement activity, statistically there was no difference between other incubation times, suggesting a short incubation time could be used to detect lysis. This is advantageous allowing for rapid diagnosis of fish health. The shorter time to activate the ACP would be useful in the implementation of this method on-farm for routine assessment of the health status of the fish. Moreover, with minimal daily variation between morning and afternoon in terms of the Asian seabass serum complement activity, this method is also robust.

In conclusion, the ACP activity, which can directly kill and eliminate microorganisms and foreign substances without the presence of antibody is a powerful defense mechanism with the potential to inhibit the establishment of invading organisms, until the specific response is developed. Hence, the ACP assay can be a rapid and sensitive indicator of fish immune responses, and the optimal conditions suggested for assessing the activation of the ACP in Asian seabass required EGTA-GVB buffer solution supplemented with $7.5 \mathrm{mM} \mathrm{MgCl} 2$ at $\mathrm{pH} 7.5$, and incubation temperature at $25^{\circ} \mathrm{C}$ for 30 minutes. This finding provides useful information for future immunological studies on Asian seabass. It can also be used as a tool to investigate the role of diet or stress on the immune responses of the species.

\section{ACKNOWLEDGEMENTS}

We would like to thank the Directorate General for Higher Education, Ministry of Research Technology and Higher Education, Republic of Indonesia, for funding SDH at the School of Animal and Veterinary Sciences, University of Adelaide, Australia. We would also like to thank Amanda Kenyon and staff in the School of Pharmacy and Medical Sciences, University of South Australia for their valued help and guidance in this project.

\section{REFERENCES}

Abram QH, Dixon B, Katzenback BA. 2017. Impacts of low temperature on the teleost immune system. Biol 6 (39): 1-15.

Biller-Takahashi JD, Takahashi LS, Marzocchi-Machado CM, Zanuzzo FS, Sabioni RE, Urbinati EC. 2012. Hemolytic activity of alternative complement pathway as an indicator of innate immunity in pacu (Piaractus mesopotamicus). Revista Brasileira de Zootecnia 41: 237241.

Boshra H, Li J, Sunyer JO. 2006. Recent advances on the complement system of teleost fish. Fish Shellfish Immunol 20: 239-262.

Chen R, Lochmann R, Goodwin A, Praveen K, Dabrowski K, Lee K-J. 2003. Alternative complement activity and resistance to heat stress in Golden Shiners (Notemigonus crysoleucas) are increased by dietary vitamin $\mathrm{C}$ levels in excess of requirements for prevention of deficiency signs. J Nutr 133: 2281-2286.

Collazos ME, Barriga C, Ortega E. 1994. Optimum conditions for the activation of the alternative complement pathway of a cyprinid fish (Tinca tinca L.). Seasonal variations in the titres. Fish Shellfish Immunol 4 (7): 499-506.

Costabile M. 2010. Measuring the 50\% haemolytic complement (CH50) activity of serum. J Vis Exp. DOI: 10.3791/1923

Hayman JR, Bly JE, Levine RP, Lobb CJ. 1992. Complement deficiencies in channel catfish (Ictalurus punctatus) associated with temperature and seasonal mortality. Fish Shellfish Immunol 2: 183-192.

Holland MCH, Lambris JD. 2002. The complement system in teleosts. Fish Shellfish Immunol 12: 399-420.

Ingram GA. 1987. Haemolytic activity in the serum of brown trout, Salmo trutta L. J Fish Biol 31 (1): 9-17.

Kirschfink M, Mollnes TE. 2003. Modern complement analysis. Clin Diagn Lab Immunol 10 (6): 982-989.

Le Morvan C, Troutaud D, Deschaux P. 1998. Differential effects of temperature on specific and nonspecific immune defences in fish. $\mathrm{J}$ Exp Biol 201: 165-168. 
Lobb CJ, Hayman JR. 1989. Activation of complement by differen immunoglobulin heavy chain isotypes of the Channel catfish (Ictalurus Punctatus). Mol Immunol 26 (5): 457-465.

Merchant ME, Verret B, Elsey RM. 2005. Role of divalent metal ions in serum complement activity of the American alligator (Alligator mississippiensis). Comparative Biochem Physiol 141: 289-293.

Montero D, Tort L, Izquierdo M, Robaina L, Vergara JM. 1998. Depletion of serum alternative complement pathway activity in gilthead seabream caused by $\alpha$-tocopherol and n-3 HUFA dietary deficiencies. Fish Physiol Biochem 18: 399-407.

Prez RM, Bryan CS, Hawiger J, Colley DG. 1975. Function of the classical and alternate pathways of human complement serum treated with Ethylene Glycol Tetraacetic and $\mathrm{MgCl}$-Ethylene Glycol Tetraacetic Acid. Infect Immun 11 (6): 1235-1243.

Sakai DK. 1981. Heat inactivation of complements and immune hemolysis reactions in rainbow trout, masu salmon, coho salmon, goldfish and tilapia. Bull Jpn Soc Sci Fish 47: 565-571.

Sakai DK. 1992. Repertoire of complement in immunological defense mechanisms of fish. Ann Rev Fish Dis 2: 223-247.
Sunyer JO, Tort L. 1995. Natural hemolytic and bactericidal activities of sea bream Sparus aurata serum are effected by the alternative complement pathway. Vet Immunol Immunopathol 45: 333-345.

Voght W, Dames W, Schmidt G, Dieminger L. 1977. Complement activation by the properdin system: Formation of stoichiometric, C3 cleaving complex of properdin factor B with C3b. Immunochem 14: 201-205.

Whyte SK. 2007. The innate immune response of finfish-A review of current knowledge. Fish Shellfish Immunol 23: 1127-1151.

Yano T, Hatayama Y, Matsuyama H, Nakao M. 1988. Titration of the alternative pathway activity of representative cultured fishes. Nippon Suisan Gakkaishi 54: 1049-1054.

Yano T, Matsuyama H, Tanaka K, Nakao M. 1987. Alternative pathway hemolytic complement titer (ACH50) of Porgy (Pagrus major) serum. Nippon Suisan Gakkaishi 53: 1887-1891.

Zhou Z, Liu H, Liu S, Sun F, Peatman E, Kucuktas H, Kaltenboeck L, Feng T, Zhang H, Niu D, Lu J, Waldbieser G, Liu Z. 2012. Alternative complement pathway of channel catfish (Ictalurus punctatus): Molecular characterization, mapping and expression analysis of factors Bf/C2 and Df. Fish Shellfish Immunol 32: 186195. 